\title{
Par Pond Water Balance ${ }^{(U)}$
}

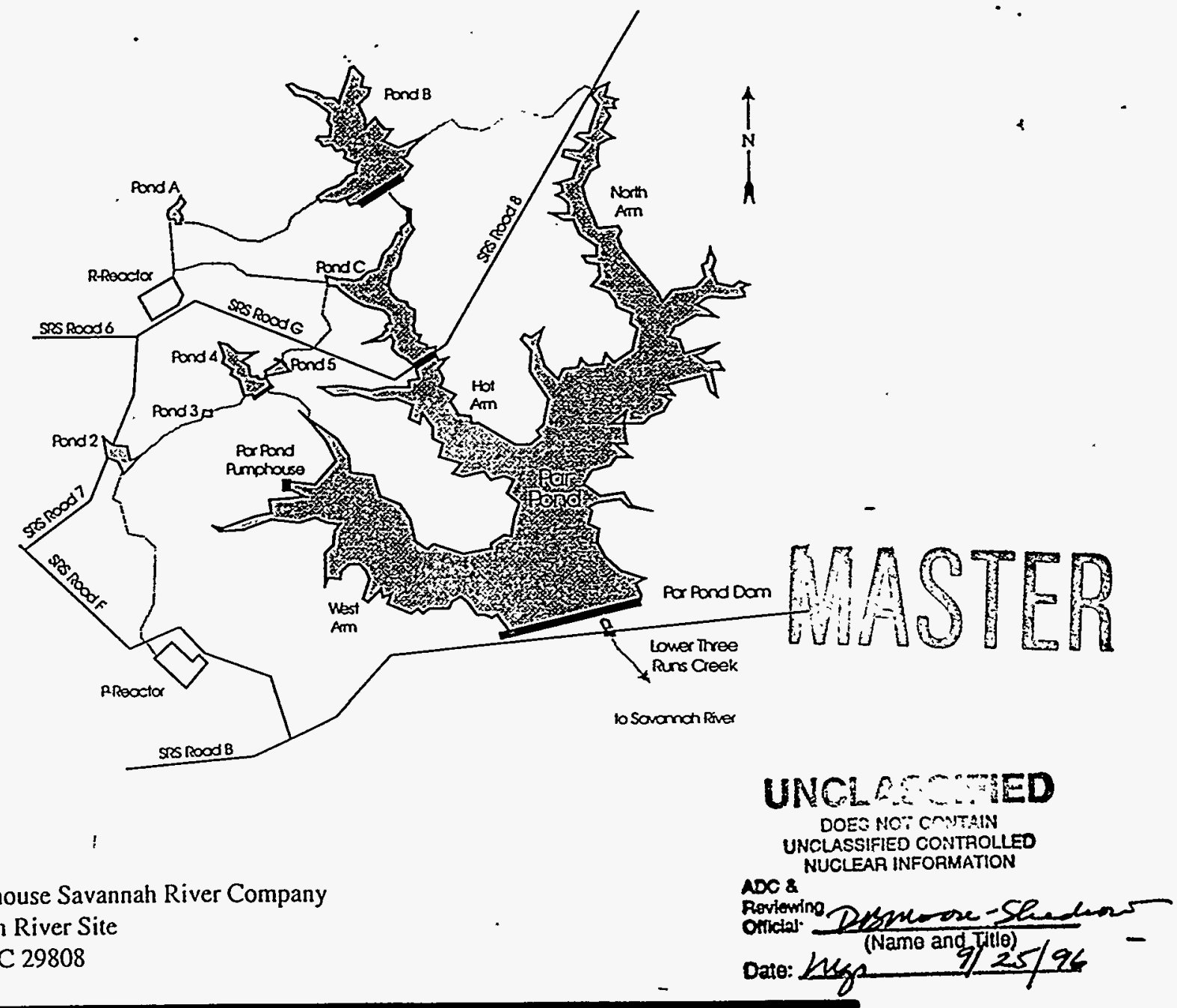

Westinghouse Savannah River Company

Savannah River Site

Aiken, SC 29808

Prepared for the U.S. Department of Energy under contract no. DE-AC09-89SR 18035

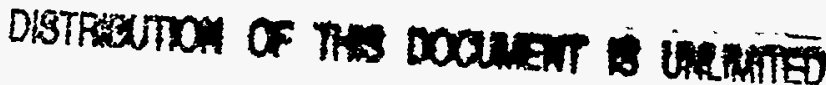




\section{DISCLAIMER}

This report was prepared as an account of work sponsored by an agency of the United States Government. Neither the United States Government nor any agency thereof, nor any of their employees, makes any warranty, express or implied, or assumes any legal liability or responsibility for the accuracy, completeness, or usefulness of any information, apparatus, product, or process disclosed, or represents that its use would not infringe privately owned rights. Reference herein to any specific commercial product, process, or service by trade name, trademark, manufacturer, or otherwise does not necessarily constitute or imply its endorsement, recommendation, or favoring by the United States Government or any agency thereof. The views and opinions of authors expressed herein do not necessarily state or reflect those of the United States Government or any agency thereof.

This report has been reproduced directly from the best available copy.

Available to DOE and DOE contractors from the Office of Scientific and Technical Information, P.O. Box 62, Oak Ridge, TN 37831; prices available from (615) 576-8401.

Available to the public from the National Technical Information Service, U.S. Department of Commerce; 5285 Port Royal Road, Springfield, VA 22161. 


\section{DISCLAMMER}

Portions of this document may be illegible in electronic image products. Images are produced from the best available original document. 
WSRC-TR-96-0161

Rev 0

June 1996

Par Pond Water Balance ${ }^{(U)}$

4

R. A. Hiergesell and K. L. Dixon

Prepared for the U.S. Department of Energy under contract no. DE-AC09-89SR18035

a 


\section{TABLE OF CONTENTS}

INTRODUCTION

PURPOSE AND SCOPE

ANALYTICAL METHODS AND COMPUTATIONS

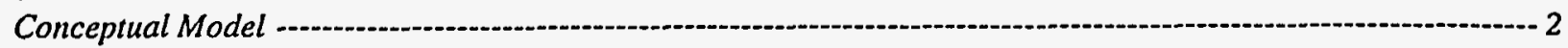

Quantification of Components

Catchment Areas - 3

Precipitation -

Evapotranspiration -..-1

Infiltration of Precipitation - 4

Groundwater Outflow to Deeper Aquifer

Groundwater Infiltration into Par Pond -

Groundwater Outflow from Par Pond- 8

Surface Runoff into Par Pond - 8

Canal Inflow to Par Pond - 9

Par Pond Spillway Discharge - 9

SUMMARY AND CONCLUSIONS

REFERENCES 


\section{Par Pond Water Balance}

\section{EXECUTIVE SUMMARY}

A water budget for the Par Pond hydrologic system was established in order to estimate the rate of groundwater influx to Par Pond. This estimate will be used in modeling exercises to predict Par Pond reservoir elevation and spillway discharge in the scenario where Savannah River water is no longer pumped and discharged into Par Pond. The principle of conservation of mass was used to develop the water budget, where water inflow was set equal to water outflow. Components of the water budget were identified, and the flux associated with each was determined. The water budget was considered balanced when inflow and outflow summed to zero.

The results of this study suggest that Par Pond gains water from the groundwater system in the upper reaches of the reservoir, but looses water to the groundwater system near the dam. The rate of flux of groundwater from the water table aquifer into Par Pond was determined to be $13 \mathrm{cfs}$. The rate of flux from Par Pond to the water table aquifer near the dam was determined to be $7 \mathrm{cfs}$.

\section{INTRODUCTION}

Par Pond is a 2400 acre man-made reservoir that was used to receive thermal effluent from reactor * operations (P and R reactors) at the Savannah River Site (SRS) (Figure 1). Construction of the reservoir was initiated in 1957 and completed in 1958, with overflow at the control structure occurring on December 30, 1958 (Wilde and Tilley, 1985). The pond was created by constructing an earthen dam across Lower Three Runs north of SRS Road B. The pond is considered at full pool at a water elevation of about $199 \mathrm{ft}$ above mean sea level. It has an average depth of about $20 \mathrm{ft}$, and a maximum depth of about $59 \mathrm{ft}$ at the dam (Wilde and Tilley, 1985).

During reactor operations, water levels in Par Pond were maintained between 199.5 and $199.9 \mathrm{ft}$ above mean sea level by pumping Savannah River water from the $1 G$ and $3 G$ pump houses. Although reactor operations were discontinued in 1988, river water continues to be pumped into Par Pond to maintain historical water levels. Due to recent budget constraints, considerable attention has been focused on the necessity and cost effectiveness of pumping river water into Par Pond to maintain a relatively constant full pool. As part of a cost savings proposal, an Environmental Impact Statement (EIS) and an Environmental Assessment (EA) has been prepared that examines alternatives to pumping river water into Par Pond; particularly, the discontinuation of pumping river water into the pond (DOE, 1995). Recent modeling exercises have shown that water levels in Par Pond would fluctuate seasonally with rainfall/runoff and evaporation, with pool levels ranging from $197-199 \mathrm{ft}$ above mean sea level (USCOE, 1994); however, these modeling exercises have some uncertainty due to assumptions made about the groundwater system at Par Pond. Due to a lack of knowledge of the hydrologic system in the Par Pond area, the assumption was made for modeling purposes, that net groundwater flux into the pond is zero (i.e. flux in equals flux out). Because of the uncertainty associated with this assumption, it has become necessary to develop a better understanding of the groundwater system at Par Pond.

The focus of this project has been to quantify the components of the hydrologic system surrounding Par Pond in order to establish a water budget for the system. The main objective of the project has been to provide an estimate of the rate of groundwater influx to Par Pond using the water budget. Results from 
this investigation will be used to predict Par Pond reservoir elevation and spillway discharge in the scenario where Savannah River water is no longer pumped and discharged into Par Pond.

\section{PURPOSE AND SCOPE}

The purpose of this project is to determine as accurately as possible the components of the water budget for the Lower Three Runs (LTR) watershed, particularly the flux term representing groundwater inflow into Par Pond. The scope of the investigation is to acquire all information relevant to quantifying each term of the water budget, devise a strategy for calculating each component and identify the assumptions that must be made to estimate particular components. It is recognized that the water budget terms vary temporally, depending on variability in natural precipitation and variability in SRS operations. The scope of this investigation does not include a characterization of that variability, but will focus on establishing long-term average rates for each component of the water budget.

\section{ANALYTICAL METHODS AND COMPUTATIONS}

\section{Conceptual Model}

The fundamental concept in calculating the water budget terms is that water inflow is equal to water outflow, also known as the principle of conservation of mass. The following terms of the water budget are identified and grouped as either inflow or outflow terms:

\section{Inflow terms}

- Precipitation over the watershed

- Precipitation over Par Pond

- Deep infiltration of precipitation over the watershed

- Runoff of precipitation

- Seepage of groundwater from the water table aquifer into Par Pond

- Canal inflow to Par Pond

Outflow terms

- Evapotranspiration from the watershed

- Evaporation from Par Pond

- Loss of groundwater from the water table aquifer to deeper aquifers

- Par Pond discharge through the spillway

- Seepage from Par Pond to the groundwater system

A schematic diagram is shown in Figure 2 illustrating the relationship of each component to the others.

\section{Quantification of Components}

Knowledge of the hydrologic system and existing measurements allow for reasonable estimates of the components to be made. Limited information exists about the Par Pond hydrologic system. This lack of information contributes to the overall uncertainty of any estimates made about the system. Currently, there is no site specific information to delineate the exact percentage of total rainfall that is lost to evapotranspiration (ET), deep percolation (leakage to water table), or runoff to surface drainageways. The accurate partitioning of rainfall among these three transport mechanisms is fundamental to the 
accuracy of the resulting water budget. For this analysis, the assumption was made that $50 \%$ of the total rainfall in the Par Pond system is lost to ET, $40 \%$ is lost to deep percolation, and $10 \%$ runs off the land surface and is transported into Par Pond. Justification for this particular partitioning scheme is given in subsequent sections.

Input data for the water budget analysis was obtained from several sources. Input data and associated references are summarized below.

$\underline{\text { Input }}$

Catchment Areas

Precipitation records for P-Area

Streamflow records for LTR and UTR

Water Level Méasurements

Regional hydrogeologic units and hydraulic properties

\section{Catchment Areas}

A key step in quantifying many of the terms of the water budget was to accurately determine the surface areas of the surface water and groundwater catchment areas, and of the Par Pond reservoir pool. Initially, the catchment areas were delineated on maps of the land surface elevation and of the water table. The outlines of each were then digitized using the earthVision program. Subsequently, the area calculation utility was then utilized to determine the area of each polygon. The outline of each is illustrated in Figure 3, and the calculated areas are listed in Table 1.

The land surface elevation coverage used to delineate the surface water catchment was the DEM data that was developed by the USGS and which is part of the SRS GIS database. This coverage was also used to delineate the Par Pond reservoir pool area. The water table map used to delineate the groundwater catchment was taken from Hiergesell (1995; Regional water table map of the SRS, 1Q95)

\section{Precipitation}

Precipitation records have been kept for many years by the SRTC Weather Center for stations at SRTC and at the P-Reactor Area. The records from the P-Reactor Area are regarded as more appropriate for use in this analysis due to the close proximity of the station to Par Pond. The long term monthly average rainfall values (January, 1969 - November, 1995) for the P-Area weather station are presented in Table 2.

\section{Evapotranspiration}

Of the rain falling on the land surface some is lost to evaporation directly back to the atmosphere. This can occur from local ponding of water or from moist soil. Additionally, that water which infiltrates the ground may be absorbed into the root system of the vegetative cover and transpired back to the atmosphere. These components are combined into the term "evapotranspiration". In this analysis the term is estimated for both the surface of Par Pond and the surface water catchment.

Average annual reservoir evaporation measured at Macon, GA was 49 in/yr (van der Leeden et al., 1991). This rate is practically identical to the 1974-1994 average annual precipitation recorded at the P-Reactor 
weather station, $49.1 \mathrm{in} / \mathrm{yr}$, and for the purposes of this water budget analysis, it is assumed that these flux terms offset one another.

Evapotranspiration was estimated in the General Separations Area (GSA) in Hubbard (1986) and Parizek and Root (1986). Hubbard used several approaches to estimate the amount of evapotranspiration, with: the estimates ranging from $64 \%$ to $79 \%$ of average annual precipitation. Parizek and Root estimated evapotranspiraton at $64 \%$ of average annual precipitation.

The LTR watershed has somewhat more permeable soils than the GSA, hence water is more rapidly lost to deep percolation. For this reason, the evapotranspiration for this analysis was estimated somewhat lower, at $50 \%$ of average annual precipitation.

Using this percentage, the long-term average evapotranspiration flux from the catchment area is estimated as follows:

Avg. Annual Precipitation $=49.1$ inches per year $=4.09 \mathrm{ft} . / \mathrm{yr}$.

Surface Water Catchment Area $=967624852 \mathrm{ft}^{2}$

Par Pond Area $=99428749 \cdot \mathrm{ft}^{2}$.

$\mathrm{ET}=(4.09) *(967624852-99428749) *(0.5)=1.78 \times 10^{9} \mathrm{ft}^{3} / \mathrm{yr}=56.3 \mathrm{cfs}$

\section{Infiltration of Precipitation}

Water that infiltrates the subsurface and migrates below the vegetative root zone, eventually recharges the groundwater flow system at the water table. This component of the water budget is influenced by many factors including duration and intensity of precipitation events, soil texture and slope, antecedent soil moisture, and land use and vegetative cover. The soil and land use factors vary from location to location at SRS, and the precipitation patterns vary from year to year. In this analysis, a value that represents the long-term conditions is estimated.

Three previous efforts have been made at SRS to define the portion of rainfall that infiltrates and recharges the water table aquifer. A water budget approach was used in each case. Two of these efforts were conducted in the GSA (Parizek and Root, 1986; and Hubbard, 1986), with the other in the vicinity of the Barnwell Low-Level Waste Facility (Cahill, 1982). Results from these analyses are presented in Table 3.

The infiltration component of the water budget must be estimated based upon rainfall records, surface water catchment area, soil texture and slope, and degree of vegetative cover. The soil texture throughout the surface water catchment area is predominantly sandy. Sandy soils have relatively high permeabilities and can readily absorb precipitation that falls on them. Additionally, the LTR catchment is heavily wooded with a dense mat of pine straw and other vegetative debris. This cover acts to inhibit overland runoff during precipitation events, and enhances infiltration and evapotranspiration.

The physical characteristics of the LTR watershed are thought to be more similar to the watersheds surrounding the Barnwell Facility than the GSA stream watersheds. For this reason, the estimated percentage of precipitation that recharges the groundwater flow system is thought to be much closer to the Cahill (1982) estimate. Thus, the percentage of precipitation that infiltrates and results in - 
groundwater recharge is estimated at $40 \%$ of the annual average precipitation falling on the LTR catchment area. Based on this assumption, infiltration is calculated as follows:

Infiltration $=($ average . annual precipitation. $) *($ g.w. catchment area - Par Pond area $) *(40 \%)$

where:

average annual precipitation $=49.1$ inches per year $=4.09 \mathrm{ft} . / \mathrm{yr}$.

groundwater catchment area $=981595850 \mathrm{ft}^{2}$

Par Pond area $=99428749 \mathrm{ft}^{2}$

Infiltration $=(4.09) *(981595850-99428749) *(0.4)=1.44 \times 10^{9} \mathrm{ft}^{3} / \mathrm{yr}=45.8 \mathrm{cfs}$

\section{Groundwater Outflow to Deeper Aquifer}

Calculation of the groundwater flux downward from the water table aquifer to the deeper Gordon Aquifer was conducted using information from the SRS regional groundwater flow model. The strategy was to evaluate the flux across the first confining layer underlying the water table aquifer based on the calibrated value for vertical hydraulic conductivity of the confining unit, and the head differential across the unit. The evaluation was conducted using the software program earthVision, and the grid files previously developed for the regional groundwater flow model

The grid files from the regional model were regridded with a 500-foot spacing and clipped so that the grid covered only the area around Par Pond and its surface and groundwater catchment areas. Grid files of the water table elevation, the Gordon Aquifer potentiometric level, the top of the Gordon Confining Unit, and the top of the Gordon Aquifer were evaluated in earthVision after nulling the grid node values outside the polygon of the groundwater catchment. The evaluation was done in the formula processor by incorporating Darcy's Law and evaluating vertical flow across the Gordon Confining Unit. A value of $7.5 \times 10^{-4} \mathrm{ft} /$ day was used as $\mathrm{K}_{\mathrm{v}}$ for the Gordon Confining Unit. This value is consistent with the regional model calibrated value of $8.0 \times 10^{-4} \mathrm{ft} /$ day.

A flux term was derived for each grid node, representing a $500 \mathrm{ft}^{2}$ area. These flux terms were then summed to arrive at the total flux term. The summed flux term for vertical upward flow was $0.15 \mathrm{cfs}$, and the summed flux term for downward flow to the deeper aquifer was $33 \mathrm{cfs}$.

\section{Groundwater Infiltration into Par Pond}

Prior to construction of Par Pond dam LTR was a groundwater sink and shallow groundwater movement was in the direction of LTR where it discharged to surface flow. The entire reach of LTR and the main tributaries gained flow from groundwater discharge beneath the area now inundated by Par Pond and also for short distances upstream from the reservoir. Streamflow in these reaches originated primarily from groundwater discharge and periodically from storm runoff.

The impact of construction of Par Pond dam, impoundment of water, and introduction of additional water that was pumped from the Savannah River have all served to alter the natural flow regime of LTR below the dam. The impoundment of water has also slightly altered the pattern of groundwater movement in the vicinity of Par Pond. Primarily, the impoundment of water has raised the water table elevation slightly in an area immediately outside the perimeter of Par Pond. The magnitude of this alteration in water table elevation is minimal along the upper reaches of Par Pond, and are more pronounced near the dam where the greatest depth of ponded water exists. In this area adjacent to the dam, the hydraulic 
gradient is reversed, and the direction of groundwater flow is away from Par Pond. Consequently, the reservoir acts to recharge the shallow groundwater system in the area near the dam. Estimation of the quantity of water seeping out of the dam and.into the groundwater flow system is addressed in a later section. This section addresses the component of groundwater that discharges into Par Pond.

Two alternative approaches were considered for estimating the flux rate of groundwater into Par Pond: 1.) the use of Darcy's Law, and 2.) the use of streamflow measurement data.

The first approach relies on an application of Darcy's Law to sub-sections of the perimeter of Par Pond. Factors that complicate the use of this approach are:

- the seepage face of the reservoir bed is sloping

- the groundwater flow-field surrounding the reservoir is three-dimensional (i.e. there is a

v vertical component of flow)

- the uncertainty associated with estimates of hydraulic conductivity and local hydraulic gradients.

To use the Darcy's Law approach the following assumptions must be made:

- Groundwater flow is entirely horizontal

- Seepage faces along the banks of Par Pond are vertical

- Hydraulic conductivity values are similar to other areas where measurements have been made

- Hydraulic gradient estimates are valid

The second approach relies on the use of stream flow measurements to estimate average annual baseflow rate in LTR. The basic assumption in this approach is that the natural baseflow in LTR, having originated as groundwater discharge, is equivalent to the current groundwater discharge rate into Par Pond. Any measurement of LTR flow rates near the dam obtained prior to its construction may be reflective of natural baseflow in LTR, and therefore reflective of current groundwater discharge to Par Pond.

Factors that complicate the use of this approach include:

- the construction of the dam has altered the natural flow characteristics of LTR such that natural baseflow can no longer be measured and characterized from the current gaging station records near the dam

- there was no stream gaging station on LTR prior to construction of the dam.

In 1951 several measurements were made of flow rates in all major streams crossing SRS. These measurements are documented in Freeman (1952). Of particular interest are the measurements made in LTR near Par Pond dam, and in Upper Three Runs (UTR) near the current gaging station at C-Road. The former is of interest because it is a measurement that may be highly reflective of natural baseflow in LTR, and the latter is of interest because it is on the only major stream on SRS that has not had it's natural flow regime altered by site operations.

The approach selected for this study was to use the available streamflow data to estimate average annual baseflow in LTR. From this estimate, the average annual groundwater discharge rate into Par Pond was determined. There is uncertainty associated with either approach, however the existence of the single 
measurement on LTR is thought to allow the calculation of the most reliable estimate of groundwater discharge to Par Pond.

To properly interpret the single measurement of flow in LTR, a comparison must be made with another surface water drainageway for which long-term monitoring of natural flow conditions has been conducted, and for which a measurement was made on the same day as the LTR measurement. The only such drainageway is UTR. This comparison is possible because single flow rate measurements were obtained from both LTR and UTR on August 28, 1951, and because long-term records are available from a stream gaging station on UTR very close to the site of the single measurement. Further, UTR is the only drainageway on SRS that has not had its natural flow characteristics impacted by site operations. Flow measured on August 28, 1951 for LTR near Par Pond dam was $11.3 \mathrm{cfs}$, and for UTR near the Road C gaging station was $141 \mathrm{cfs}$ (Freeman, 1952).

Other important information for this analysis is from U.S.G.S stream gaging station 02197310 , located on UTR close to where the 1951 measurement was obtained. This station was established in 1974 and has provided continuous daily measurements since that time. Table 5 presents long-term (1974-1994) average monthly low, high, and average-flow rates. The low-flow term represents the lowest daily measurement obtained during any given month and probably is reflective of the baseflow contribution. The high-flow term represents the highest daily measurement obtained during any given month and reflects baseflow plus surface runoff from precipitation events. The average flow term is an average of all daily measurements obtained during any given month.

The variation of the long-term monthly low-flow, high-flow, and mean-flow terms throughout the year * can be seen in Figure 4. The highest monthly mean-flow rates occur from January-March while the lowest monthly mean-flow rates occur from June through October. Variability is due to seasonal variation in climatic conditions. Also, this figure illustrates a comparison of daily flow rates, measured during water year 1994, with the long-term average high, low and mean flow rates for each month. The distinct peaks in flow rate for UTR result from surface runoff from precipitation events in the UTR watershed. The troughs between peaks are reflective of groundwater contribution rates to streamflow (i.e. baseflow). When comparisons of mean flow rates from the same month are made, it is evident that stream baseflow varies from month to month in the same year as well as from year to year,

Figure 5 illustrates monthly average flow rates for UTR at Road C for the period of record (1974-1994). The flow rates illustrated include mean monthly low-flow, average monthly mean-flow, an estimated average monthly baseflow rate, an average annual baseflow rate and the one-time measurement of streamflow from August 28, 1951.

The average monthly baseflow rate is estimated to fall between the average monthly low-flow and the average monthly mean flow rate, and in this investigation it is taken to be the low flow $+(0.4)$ multiplied by the difference between the two average monthly flow rates. Figure 5 illustrates that monthly average baseflow varies throughout the year, from a high in March to a low period from June through September. For the purpose of this water budget study, an average annual baseflow is calculated, and is defined to be the mean of the average monthly baseflow rates. This average value, calculated at $162 \mathrm{cfs}$, is shown as a horizontal line in Figure' 5.

The one-time measurement of UTR flow from August 28, 1951 is plotted on Figure 5 so that comparisons with long-term average monthly mean-flow, low-flow and baseflow rates can be made. The one-time measurement was $141 \mathrm{cfs}$, or $87 \%$ of the average annual baseflow for UTR at Road C. Conversely, the average annual baseflow rate in UTR at Road C is $115 \%$ of the one-time measurement from August of 1951. 
The average annual baseflow in LTR is estimated using this relationship and the measured value of LTR flow from August 28, 1951.

LTR average annual baseflow $=(11.3 \mathrm{cfs}) *(1.15)=13 \mathrm{cfs}$

\section{Groundwater Outflow from Par Pond}

The flux of Par Pond water seeping from the reservoir to the shallow groundwater flow system was approximated by assuming a simplifying geometry of the actual flow paths and using Darcy's Law.

The flow zones where groundwater is seeping from Par Pond are in the vicinity of the dam. Most of the seepage occurs beneath the dam, however water also seeps out along two stretches of the reservoir immediately adjacent to the dam. From each end of the dam, these stretches extend along the reservoir perimeter to a point where the groundwater catchment area diverges from the reservoir shoreline. The location of each of these points is approximate, and is based upon the regional water table map in the vicinity of Par Pond. This can easily be seen in Figure 3. Water levels measured in several wells in the area confirm that the flow direction in the water table is away from Par Pond in the area just west of the dam.

To calculate seepage from Par Pond, the area of seepage was divided into three sections. These are the . dam, the left wing, and the right wing. The left wing is west of the dam and the right wing is to the east. A separate calculation is made for each of these sections and a summation made to estimate total seepage.

For each of the flow sections, the geometry of the flow path is through a rectangular prism assumed to be representative of the actual flow path from Par Pond to the discharge point below the dam, on LTR. The dimensions of each prism were based on the depth from the water table to the underlying confining unit, on the width of the flow path (i.e. dam width, wing width) and the length of the flow path.

Darcy's law was used to calculate flow through each prism:

$\mathrm{Q}=\mathrm{K} *(\mathrm{dH} / \mathrm{dL}) * A$

where $Q=$ the groundwater flux term

$\mathrm{K}=$ hydraulic conductivity $[\mathrm{L}] /[\mathrm{t}]$

$\mathrm{dH}=$ hydraulic head differential $[\mathrm{L}]$

$\mathrm{dL}=$ length of flow path [L]

$A=$ area over which flow occurs $[L]^{2}$

Representative values for $\mathrm{K}, \mathrm{dH}, \mathrm{dL}$, and $\mathrm{A}$ were selected and are presented in Table 4 . Based on these input parameters into Darcy's Law, the estimated total seepage outflow from Par Pond to the groundwater system is $6.8 \mathrm{cfs}$.

\section{Surface Runoff into Par Pond}

There is no stream gaging station on the upstream reach of LTR, or any other tributary to Par Pond, to allow quantification of the amount of surface runoff that enters Par Pond. Consequently, this component of the water budget must be estimated based upon rainfall records, surface water catchment area, soil texture and slope, and degree of vegetative cover. 
The soil texture throughout the surface water catchment area is predominantly sandy. The most common soil types being Lakeland sand, Fuquay sand, and Blanton sand with relatively gentle 0 to $6 \%$ slopes (Rogers, 1990). Sandy soils have relatively high permeabilities and can readily absorb precipitation that falls on them. Additionally, the catchment is heavily wooded with a dense mat of pine straw and other vegetative debris. This cover acts to inhibit overland runoff during precipitation events, and enhances infiltration. The runoff that does occur probably occurs primarily along existing drainageways, many of which are flanked by steeper slopes.

Based on the physical characteristics of the watershed, an assumption is made that $10 \%$ of the annual average precipitation falling on the catchment results in runoff that finds its way into Par Pond.

Using this assumption, surface runoff is calculated as follows:

Runoff $=$ (average annual. precipitation $) *($ s.w. catchment area - Par Pond area $) *(10 \%)$

where:

- Average. Annual Precipitation $=49.1$ inches per.year $\doteq 4.09 \mathrm{ft} . / \mathrm{yr}$.

Surface Water Catchment Area $=967624766 \mathrm{ft}^{2}$

Par Pond Area $=99428749 \mathrm{ft}^{2}$

Runoff $=(4.09) *(967624766-99428749) *(0.1)=3.55 \times 10^{8} \mathrm{ft}^{3} / \mathrm{yr}=\mathbf{1 1 . 3} \mathrm{cfs}$

\section{Canal Inflow to Par Pond}

To facilitate cooling at the $\mathrm{P}$ and $\mathrm{R}$ Reactors, Savannah River water was pumped to the reactors and eventually discharged through a canal system to Par Pond. $R$ Reactor was shut down prior to installation of the USGS gaging station immediately below the dam, so summary statistics of Par Pond releases from that station will reflect only the impact of P Reactor operations. Summary statistics of the discharge rate of Savannah River water to the canal are provided by Wilde and Tilley (1985).

Wilde and Tilley (1985) state that Savannah River makeup water was pumped at a rate of 1.0 to $1.3 \mathrm{~m}^{3} / \mathrm{s}$ ( 35.3 to $45.9 \mathrm{cfs}$ ) during the time of reactor operation and at a rate of 0.6 to $0.8 \mathrm{~m}^{3} / \mathrm{s}(21.19$ to $28.25 \mathrm{cfs})$ when the reactor was not operating. The reactor has not been operating since 1988, although some water has continued to be pumped from the Savannah River and discharged to the canal system since that time. The pumping rate after reactor shut-down has been in the 7 to $11 \mathrm{cfs}$ range.

Because the reactor did not run continuously, and because there was some canal transmission losses to seepage and evaporation, it is estimated that a representative long-term (1974-1994) discharge rate from the canal into Par Pond is $\mathbf{2 3}$ cfs.

\section{Par Pond Spillway Discharge}

USGS stream gaging station 02197380 (USGS, 1994)is located on LTR where SRS Road B crosses the drainageway. The gaging station is located immediately downstream from the dam spillway discharge point, and essentially records Par Pond release rates. This station was established in 1974 and provides a record of flow from that time to the present. 
Summary statistics reported by the USGS (USGS, 1994) provide a period of record mean flow rate of 39.9 cfs.

\section{SUMMARY AND CONCLUSIONS}

The purpose of this project has been to determine as accurately as possible the components of the water budget for the Lower Three Runs (LTR) watershed, particularly the flux term representing groundwater inflow into Par Pond. This project has focused on long-term average rates and assumes no change in water storage, either in the groundwater/surface water system surrounding PAR Pond or in PAR Pond itself. Consequently, estimates of inflow to PAR Pond must be equal to estimates of outflow, just as the same principle must hold true for the entire hydrologic system surrounding PAR Pond. The components associated with inflow and outflow have been identified and quantified in this report. Table 6 presents a listing of each component and the flux rate, in cubic feet per second. These water budget terms are also illustrated schematically in Figure 6, which shows the relationship between particular components and their relationship to PAR Pond.

While the water budget has been calculated for the entire surface and ground water catchment surrounding Par Pond, not all of the terms listed in Table 6 are actual inflow or outflow terms for PAR Pond itself. The water budget components that represent actual fluxes in to or out of PAR Pond are listed below.

Inflow Terms

\begin{tabular}{l|c}
\hline Water Budget Component & $\begin{array}{c}\text { Long-term Average Flux Rate } \\
\text { (cfs) }\end{array}$ \\
\hline Precipitation over PAR Pond & 13 \\
Surface runoff entering PAR Pond & 11 \\
Groundwater seepage into PAR Pond & 13 \\
Long-term average canal inflow to Par Pond & 23 \\
\hline Total & 60 \\
\hline
\end{tabular}

Outflow Terms

\begin{tabular}{l|c}
\hline Water Budget Component & $\begin{array}{c}\text { Long-term Average Flux Rate } \\
\text { (cfs) }\end{array}$ \\
\hline Evapotranspiration from PAR Pond & 13 \\
Seepage loss to groundwater & 7 \\
Spillway discharge & 40 \\
\hline Total & 60 \\
\hline
\end{tabular}

The sum of the inflow terms is equal to the sum of the outflow terms. Consequently, the quantifications calculated in this report exhibit a balance between inflow and outflow. 


\section{REFERENCES}

Bebbington, W.P. 1990. History of Du Pont at the Savannah River Plant. E.I. du Pont de Nemours \& Co. Wilmington, DE.

del Carmen, B.R. and M.H. Paller. 1993. Lower Three Runs instream flow study. WSRC-TR-93-679. Westinghouse Savannah River Company, Savannah River Technology Center. Aiken, SC.

Ezra, C.E. and L.R. Tinney. 1985. Par Pond Macrophyte Study, Savannah River Plant, Aiken South Carolina. EG\&G Energy Measurements, Inc. Las Vegas, NV.

Freeman, H.W. 1954. An ecological study of the land plants and cold-blooded vertebrates of the Savannah River Project area. Part II. Fishes of the Savannah River Project area. University of South Carolina Publications, Biology Series III, 1-117-116.

Freeze, R.A. and J.A. Cherry. 1979. Groundwater. Prentice-Hall, Inc. Englewood Cliffs; NJ.

Geraghty, J.J., D.W:Miller, F. van der Leeden, and F.L. Troise. 1973. Water Atlas of the United States. Water Information Center. Port Washington, NY.

Hiergesell, R.A. 1995. Regional water table map of the Savannah River Site, 1Q95. WSRC-MS-950524. Westinghouse Savannah River Company, Savannah River Technology Center. Aiken, SC.

Jensen, J.R., S. Narumalani, O. Weatherbee, and H.E. Mackey, Jr. 1993. Measurement of seasonal and yearly cattail and waterlily changes using multidate SPOT panchromatic data. Photogrammatic Engineering and Remote Sensing, Vol. 59, No. 4.

Neill, J.S. and D.F. Babcock. 1971. The dissipation of reactor heat at the Savannah River Plant. DP1274. E.I. du Pont de Nemours \& Co., Savannah River Laboratory. Aiken, SC.

Rogers, V.A. 1990. Soil Survey of the Savannah River Plant Area, Parts of Aiken, Barnwell, and Allendale Counties, South Carolina. Soil Conservation Service, U.S. DePartment of Agriculture.

U.S. Army Corps. of Engineers (USCOE). 1994. Par Pond Reservoir Level Study. Project No. PC2071.94.001. U.S. Army Corps of Engineers, Charleston, SC.

U.S. Department of Energy (USDOE). 1995. Draft Environmental Assessment for the Natural Fluctuation of Water Level in Par Pond and Reduced Water Flow in Steel Creek Below L-Lake at the Savannah River Site. DOE/EA-0000. U.S. Department of Energy, Savannah River Operations Office, Aiken SC.

U.S. Geological Survey (USGS). 1994. Water Resources Data - South Carolina: Water Year 1994. Water-Data Report SC-94-1. U.S. Geological Survey, Columbia, SC.

van der Leeden, F., F.L. Troise, and D.K. Todd. 1991. The Water Encyclopedia. Lewis Publishers. Chelsea, MI.

Wilde, E.W. and L.J. Tilly. 1985. Influence of P-Reactor operation on the aquatic ecology of Par Pond: A literature review. DP-1698. E.I. du Pont de Nemours \& Co, Savannah River Laboratory. Aiken, SC. 
Table 1. Results of area calculations for Par Pond and its catchment areas.

\begin{tabular}{l|c|c}
\hline & Area (acres) & Area $\left(\mathrm{ft}^{2}\right)$ \\
\hline Surface Water Catchment & 22213.61 & 967624766 \\
Groundwater Catchment & 22534.35 & 981596109 \\
Par Pond (200 ft. pool) & 2282.57 & 99428834 \\
\hline
\end{tabular}

Table 2. Precipitation data for the P-Area weather station (January, 1969 - November, 1995).

\begin{tabular}{c|c|c}
\hline Month & $\begin{array}{c}\mathrm{P} \\
\text { (in) }\end{array}$ & $\begin{array}{c}\mathrm{P} \\
\text { (cm) }\end{array}$ \\
\hline January & 4.68 & 11.88 \\
February & 4.34 & 11.01 \\
March & 4.62 & 11.73 \\
April & 3.05 & 7.75 \\
May . . & 3.69 & 9.36 \\
June & 5.09 & $12.94 .$. \\
July & 3.93 & 9.97 \\
August & 5.33 & 13.53 \\
September & 3.28 & 8.33 \\
October & 3.54 & 9.00 \\
November & 2.85 & 7.25 \\
December & 3.64 & 9.24 \\
\hline Average Annual & 49.1 & 124.83 \\
\hline
\end{tabular}

Table 3, Estimates of groundwater recharge to the water table as a percent of precipitation

\begin{tabular}{l|c}
\hline & $\begin{array}{c}\text { Groundwater recharge as a percent of } \\
\text { precipitation }\end{array}$ \\
\hline Parizek and Root (GSA)' & 30 \\
Hubbard (GSA) & 32 \\
Cahill (Barnwell Facility) & 40 \\
\hline
\end{tabular}

${ }^{1}$ General Separations Area

Table 4. Parameters used to calculate groundwater outflow from Par Pond.

\begin{tabular}{l|c|c|c|c|c}
\hline & $\begin{array}{c}\mathrm{K} \\
(\mathrm{ft} / \mathrm{day})\end{array}$ & $\mathrm{dH} / \mathrm{dL}$ & $\begin{array}{c}\mathrm{A} \\
\left(\mathrm{ft}^{2}\right)\end{array}$ & $\begin{array}{c}\text { Conversion factor } \\
\text { to } \mathrm{cfs}\end{array}$ & $\begin{array}{c}\mathrm{Q} \\
(\mathrm{cfs})\end{array}$ \\
\hline Left Wing & 15 & 0.009406 & 728650 & $1.15741 \mathrm{E}-05$ & 1.19 \\
Right Wing & 15 & 0.009806 & 423020 & $1.15741 \mathrm{E}-05$ & 0.96 \\
Dam & 15 & 0.055310 & 507650 & $1.15741 \mathrm{E}-05$ & 4.87 \\
\hline
\end{tabular}


Table 5. Average Monthly Low, Mean, and High Flow Rates for UTR from measurements obtained at USGS gaging station 02197310.

\begin{tabular}{c|c|c|c}
\hline & $\begin{array}{c}\text { Average Low Flow } \\
\text { Rate (cfs) }\end{array}$ & $\begin{array}{c}\text { Average Mean Flow } \\
\text { Rate (cfs) }\end{array}$ & $\begin{array}{c}\text { Average High Flow } \\
\text { Rate (cfs) }\end{array}$ \\
\hline Oct & 186 & 134 & 394 \\
Nov & 204 & 145 & 296 \\
Dec & 211 & 132 & 272 \\
Jan & 237 & 147 & 402 \\
Feb & 237 & 149 & 307 \\
Mar & 249 & 161 & 377 \\
Apr & 217 & 141 & 334 \\
May & 192 & 129 & 321 \\
Jun & 184 & 112 & 267 \\
Jul & 187 & 113 & 304 \\
Aug & 193 & 124 & 401 \\
Sep & 180 & 105 & 237 \\
\hline
\end{tabular}

Table 6. Summary of water budget components and long-term average flux rates.

\begin{tabular}{l|c}
\hline Water Budget Component & $\begin{array}{c}\text { Long-term } \\
\text { (cfs) }\end{array}$ \\
\hline Precipitation over catchment areas & 114 \\
Precipitation over PAR Pond & 13 \\
Evapotranspiration over catchment areas & 56 \\
Evapotranspiration over PAR Pond & 13 \\
Infiltration of precipitation to water table & 46 \\
Vertical flux of groundwater from water table & 33 \\
to deeper aquifer & \\
Surface runoff of precipitation to PAR Pond & 11 \\
Discharge of groundwater to PAR Pond & 13 \\
Canal Inflow to PAR Pond & 23. \\
Loss of water from PAR Pond to groundwater & 7 \\
PAR Pond spillway discharge & 40 \\
\hline
\end{tabular}




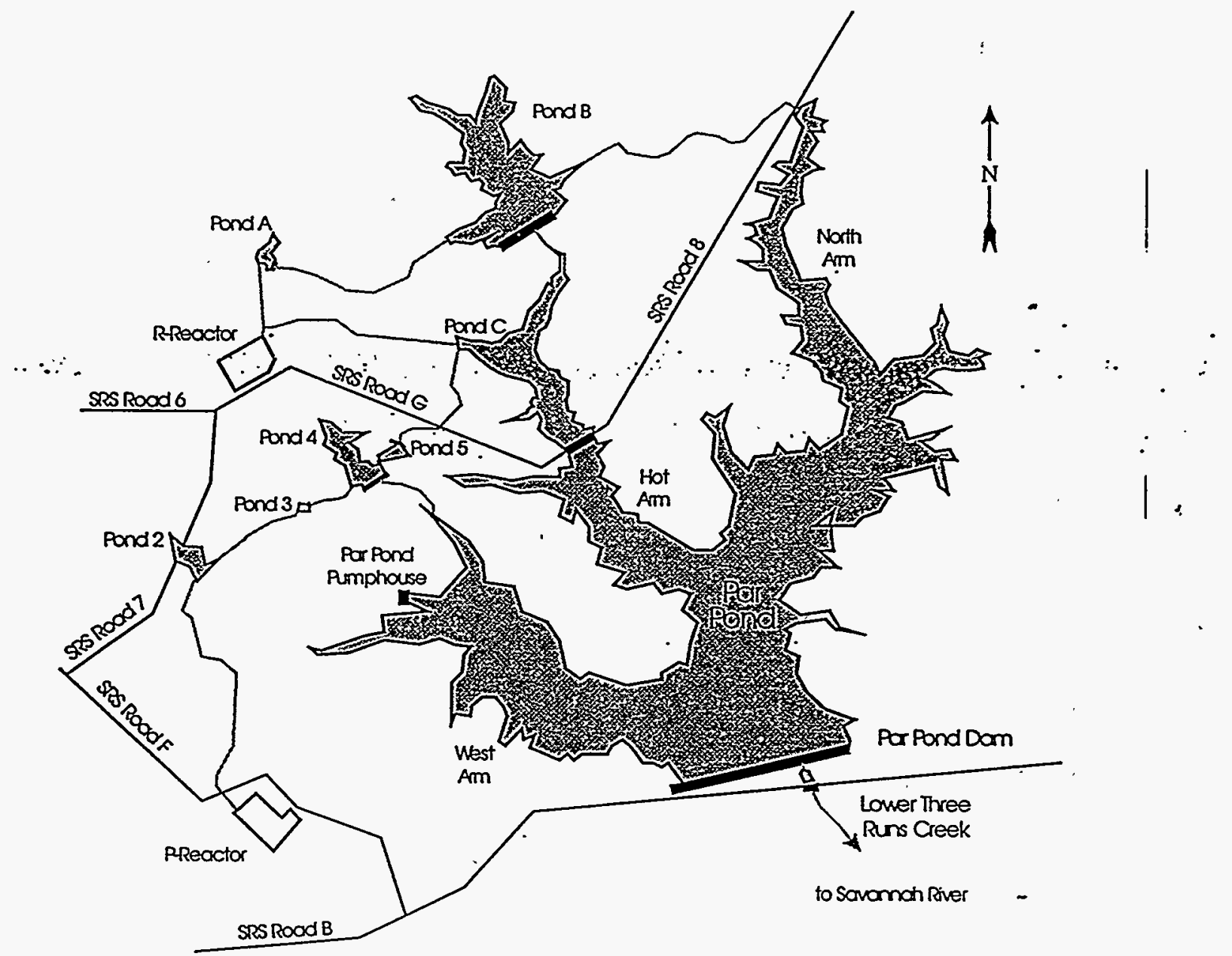

1.

Figure 1. Location of Par Pond and the P-and R-Reactor canal system. 
$=$

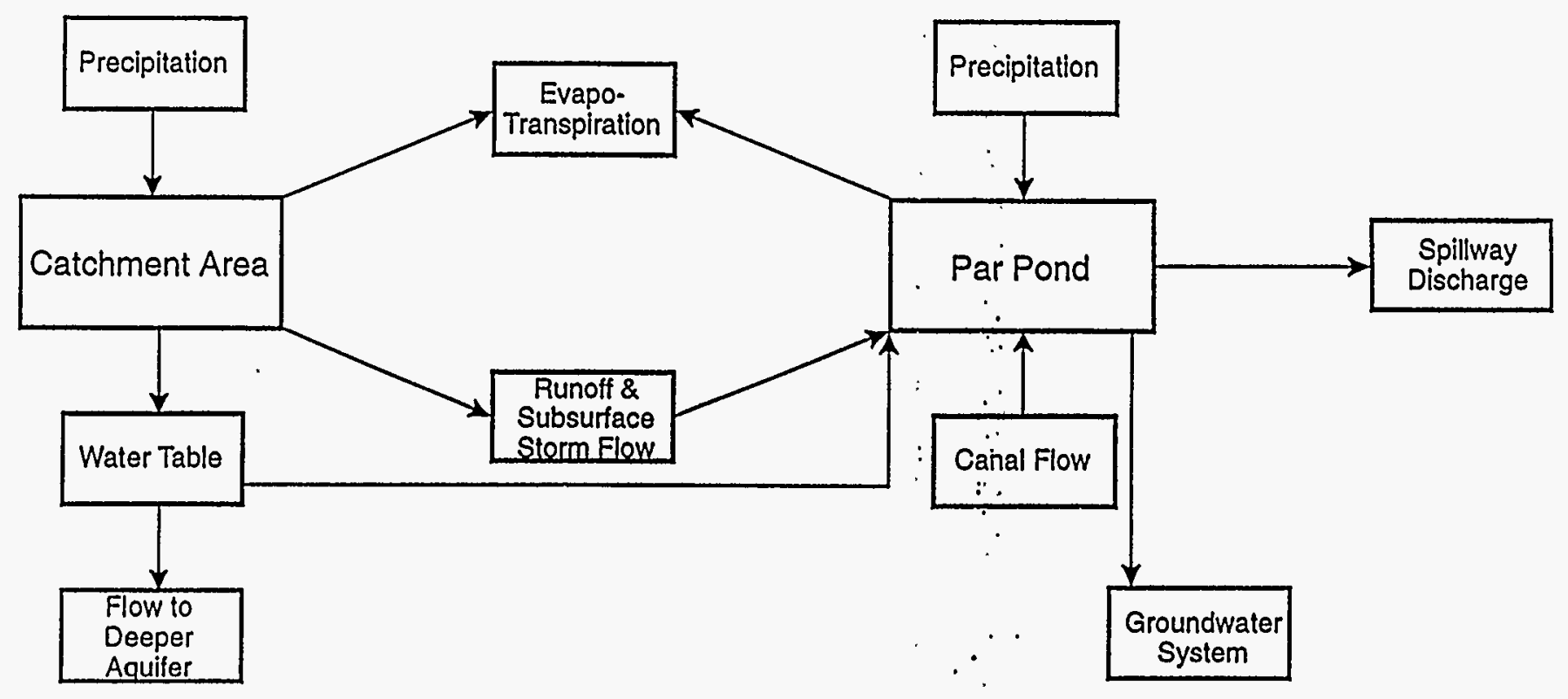

Figure 2. Schematic diagram of the conceptual model used to describe the Par Pond hydrologic system. 


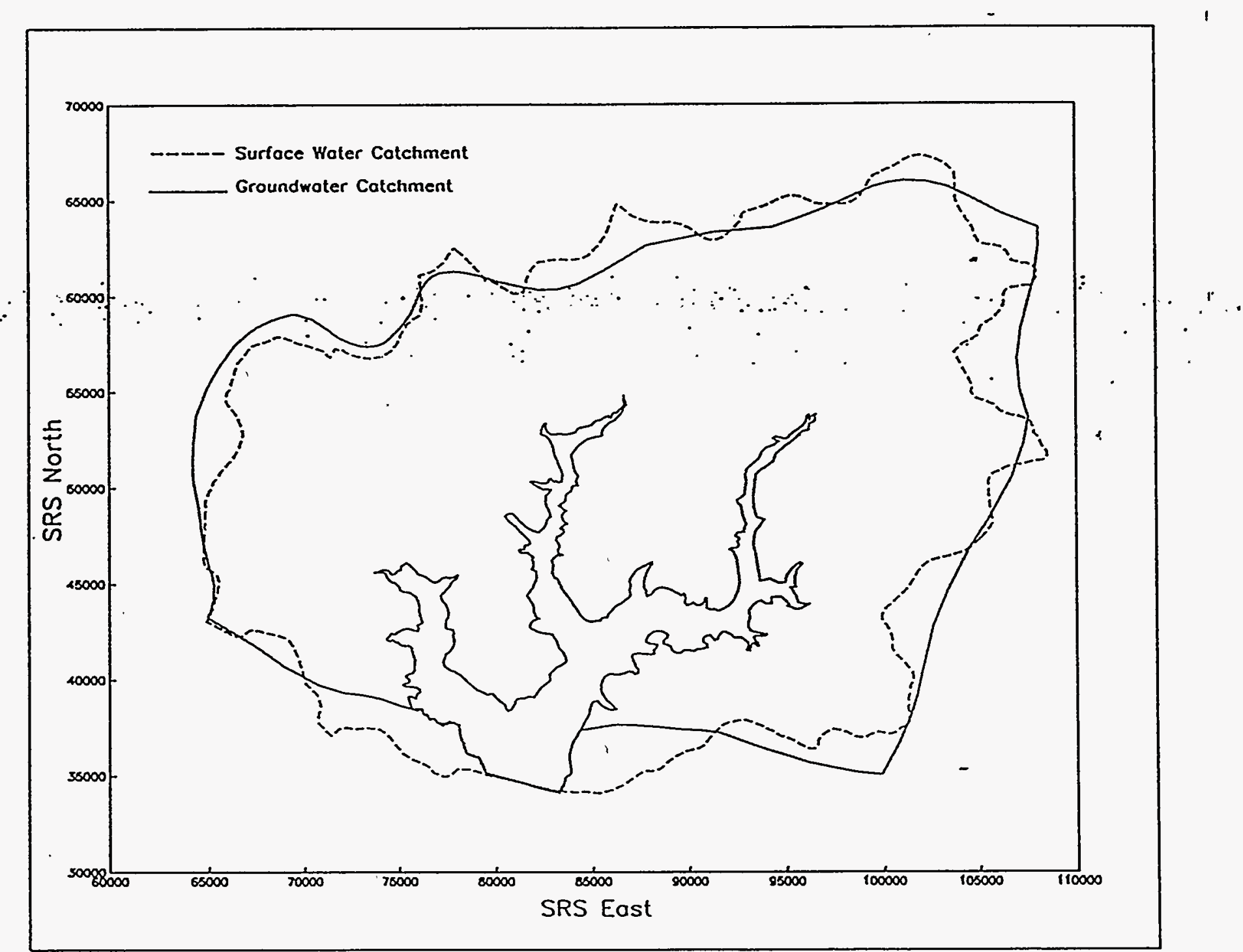

11

Figure 3. Surface water and groundwater catchment areas for the Par Pond watershed. 


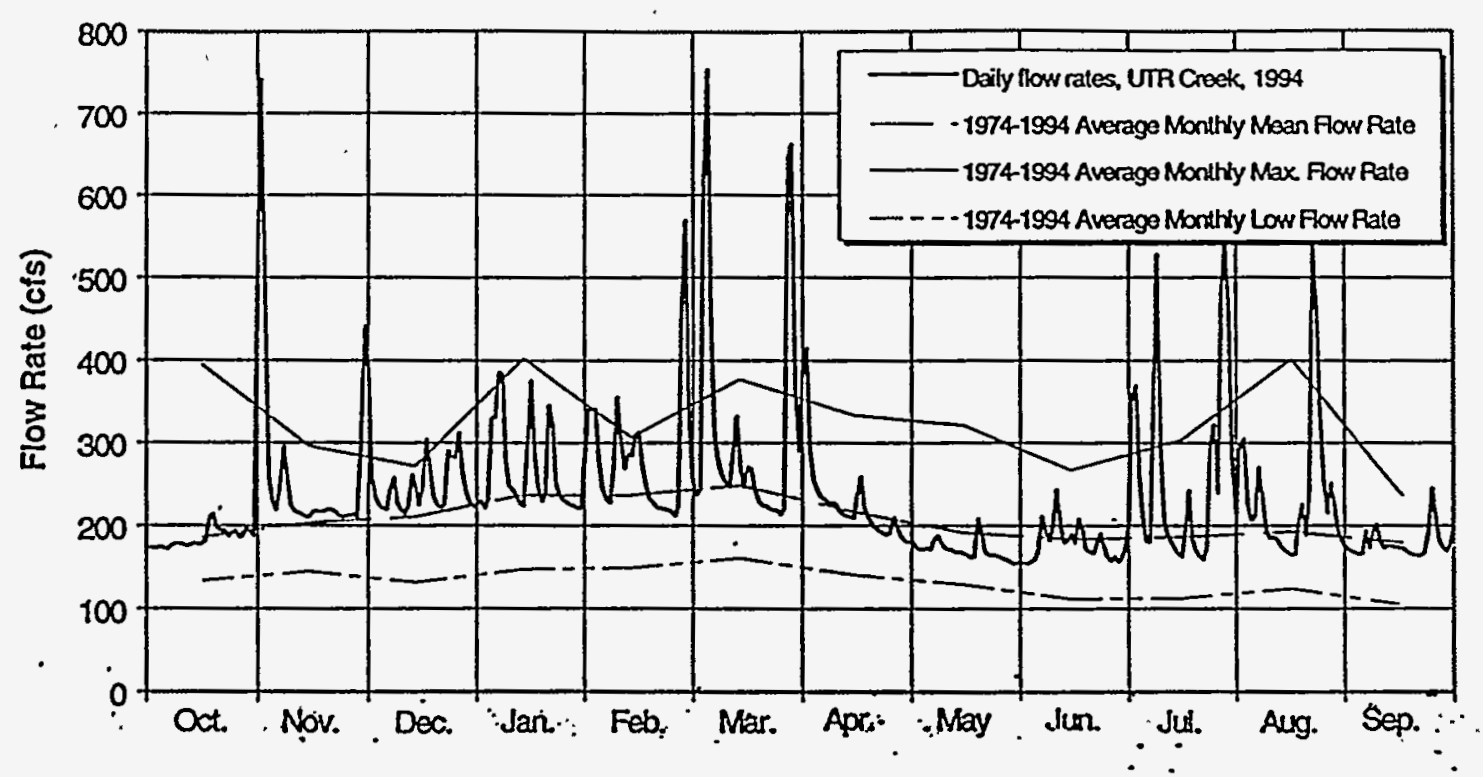

Figure 4. Comparison of 1994 daily flow rates with long-term averaged monthly rates for UTR at Road C.

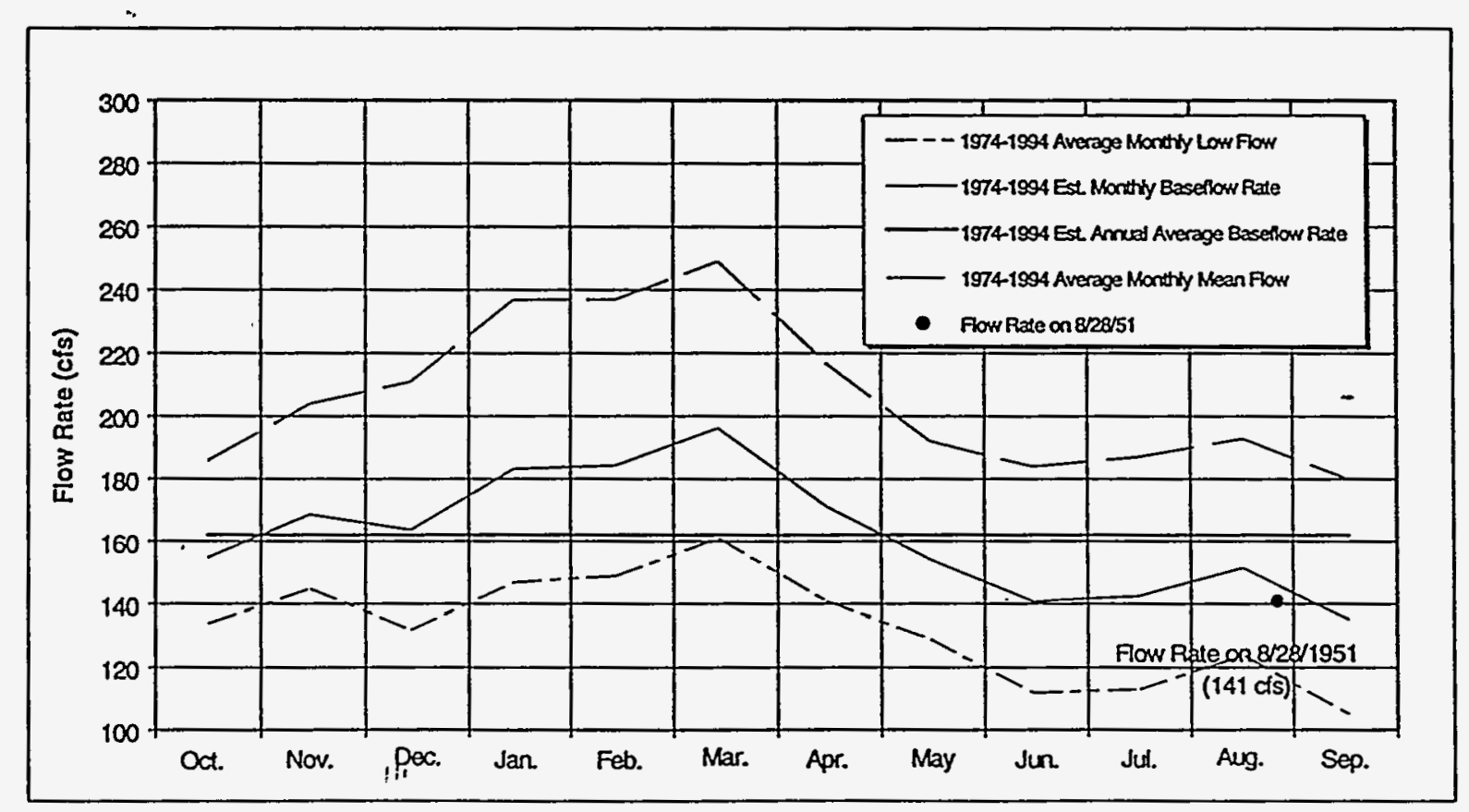

Figure 5. Monthly average flow rates for UTR at Road C (1974-1994). 


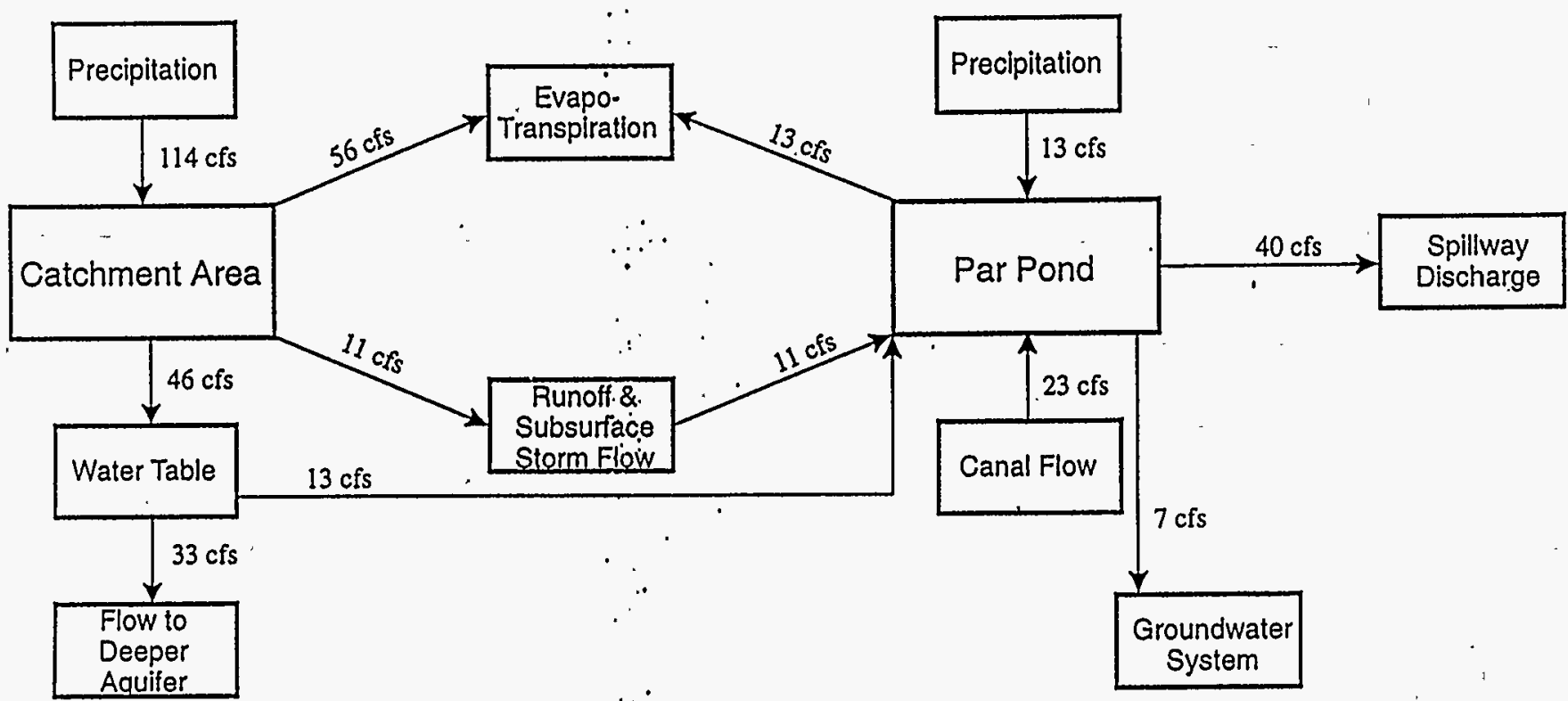

Figure 6. Schematic diagram of the conceptual modeliused to describe the Par Pond hydrologic system with the flux associated with each component. 